\title{
Effect of labelled information and sensory attributes on consumers' intention to purchase milk
}

\begin{abstract}
Purpose- The present study examines the influences of consumer perceptions of labelled information and sensory attributes on consumers' intention to buy fresh milk.

Design/methodology/approach- An experiment was conducted on 117 consumers in a lab at a university. After closely inspecting the labels' information and tasting two types of milk, participants were asked to fill in a questionnaire, using the direct interview method. Exploratory factor analysis, confirmatory factor analysis, and structural equation modelling were applied to analyse the data.

Findings- The results show that products' labelled information and the sensory perceptions increase the buying intention of both ultra-high temperature treated fresh milk (UFM) and pasteurized fresh milk (PFM). The sensory perceptions of PFM can mediate the relationship between products' labels and consumer buying intentions but this relationship is not true for UFM. According to our results, nutritional facts and taking responsibility for one's health are the keys to fresh milk commercialization in terms of higher relative weights and commonness.

Originality/value- Although the sensory aspects of milk have been rigorously evaluated in the food science literature, to the best of the authors' knowledge, few studies have focused on the sensory perceptions of fresh milk incorporating process categories (UFM and PFM) and their mediating effect between labelled information and buying intention in the social sciences. The study is pioneering in that it investigates the perceptions of sensory attributes affecting consumer purchasing decisions for fresh milk in an emerging market.
\end{abstract}

Keywords: Labelled information, Sensory attributes, Buying intention, Fresh milk, Bangladesh.

Paper type Research paper

\section{Introduction}

The major source of fresh milk, like other fresh foods, is from local producers and it is sold as a common product (Van Dam and Van Trijp, 2007). Evidence has shown that having purchase experience and being curios about new items, consumers seek new goods within a particular product category (Morgan, 1978). Thus, product category, such as the type of fresh milk categorized by processing technique (e.g. UHT or conventional pasteurisation), has been considered as an important variable for consumers' evaluation (Raghunathan and Irwin, 2001) and finding and understanding differences in product labelling (Trijp et al., 1996). Therefore, consumers with previous knowledge of a particular food, hereafter the process category of fresh milk, are more likely to use label information effectively in evaluation (Miller and Cassady, 2015). Additionally, consumers' adoption of product-process pattern ${ }^{1}$ is higher than a process-product pattern (Damanpour \& Gopalakrishnan, 2001), thus, information regarding products' processing characteristics is vital for consumers (Banterle et al., 2012).

\footnotetext{
${ }^{1}$ In a product-process pattern, firms adopt product innovations first and process innovations later.
} 
Product labels convey information regarding the product category and a variety of productspecific attributes (Morris, 1997) that lead to increased buying behaviour (Hussin et al., 2013; Khuong and Nguyen, 2015). Even in the complex retail-choice environment, product labels influence shoppers' purchase decisions by offering cues to simplify their evaluative and choice processes (Bettman et al., 1998). Consumers use labels, and intrinsic and extrinsic attributes, of food products as cues in forming their opinions regarding quality (Veale et al., 2006; Bandara et al., 2016). Currently, with the help of cues, consumers make $82 \%$ of their purchase decisions inside the store (Point of Purchase Advertising International, 2014). Previous research has shown that consumers are heterogeneous in their reliance on both intrinsic and extrinsic cues as well as in their ability to assess product cues accurately (Alba, 2000; Kardes et al., 2001). Veale et al. (2006), therefore, concluded that marketing practitioners need to understand the respective influences of product category and companies should strive to understand consumers' perceptions of their food products (see also Varela et al., 2010).

Troye and Supphellen (2012) concluded that consumers bias their sensory perceptions in self-producing products (e.g. perceived level of saltiness of a homemade vegetable soup) so that they match a positive evaluation of the outcome. Milk is a functional food (Bhat and Bhat, 20111) but not self-producing; therefore, we argue that consumers do not bias their sensory perceptions when drinking milk. Consumers have to trade the sensory (e.g. taste) and health factors over its intrinsic and extrinsic attributes (Ares et al., 2010). The literature suggests that consumers' impressions of the sensory attributes of foods affect their food choice (Sørensen et al., 2003). However, the influences of non-sensory and sensory factors on consumers' perceptions of functional foods have been little studied. As a functional food, most of the previous studies on milk have focused on, for example, assessing the microbiological quality of milk (Islam et al., 2018), evaluating fermented caprine milk's perceptions (Bessa et al., 2016), the effects of TV commercials on customers' buying behaviour (Khuong and Nguyen, 2015), production sustainability (Asselt et al., 2015), demand and market opportunities (Kuma et al., 2012; Cheng et al., 2014), demand and supply (Chavas and Klemme, 1986; Popescu, 2015), comparing flavour and texture (Oupadissakoon et al., 2009), consumption frequency and patterns (Grebitus et al., 2007), and consumers' perceptions and attitudes towards milk (Melinda and Deeth, 2001). Little literature has measured the consumers' perceptions of attributes like labelling information (extrinsic cue) and sensory (intrinsic cues) on purchase intentions for milk. This study aims to fill in this knowledge gap.

Kathuria and Gill (2013) and Sijtsema et al. (2012) argued that evaluating the quality of fresh food is difficult before consumers taste it. However, in this study, an experimental design was used in which participants were exposed as consumers and tasted two different categories of fresh milk (UHT and conventional pasteurized) to evaluate their perceived value of sensory attributes but quality. After they had closely inspected the labelled information and tasted the milk, they were asked to fill in a questionnaire including questions about the perceptions of sensory attributes and labelling information of the tasted milk. Confirmatory factory analysis (CFA) and structural equation modelling (SEM) were the main research methods employed.

The structure of the study is as follows. A review of the literature is followed by the development of hypotheses and a conceptual model. The empirical model and data collected are then discussed. Subsequently, the research results are discussed, followed by concluding remarks, managerial implications, and directions for further research. 


\section{Literature review}

Choice is the bedrock of human beings' identity: what previous generations viewed as matters of birth, luck, and social rank are now areas of choice, e.g. the choice of goods to consume (Gabriel, 2015). Consumers are becoming more educated, health conscious, and thus have begun to consider food attributes more carefully when choosing food items (Quah and Tan, 2010), with cognitive and affective factors acting as predictors of product choices (Yoo and MacInnis, 2005). From an interdisciplinary perspective, consumer choice covers everyday purchasing to extreme forms of compulsive and addictive consumption. Thus, a simple multidimensional model that eclectically incorporates variables is insufficient. The required framework should incorporate explanatory variables, e.g. social, psychological, economic, and neurophysiological, etc., that influence choice (Foxall, 2010). Again, the presentation of decision elements may have important effects on consumers' choice (Thaler and Sunstein, 2008).

Consumers search for products by using product labels relating to each dimension of the representation (Morris, 1997). In the case at hand, as per choice rules, we believe that consumers understand the two process dimensions of fresh milk by considering the products labels (Trijp et al., 1996) and use intrinsic and extrinsic attributes as cues in forming their opinions regarding quality (Veale et al., 2006) that influence consumers' choice of fresh milk category: UHT or pasteurised (Orquin and Scholderer, 2011). If their first choice is unavailable, consumers also reject their second choice if their perceived value of that products' attributes is not strong (Wendy, 2012). Thus, the quality of fresh food is vital and is affected by external factors (Riezebos and Zimmermann, 2005). Behavioural learning theory indicates that learning is a result of a response to external factors. Products labels convey information regarding a variety of product-specific attributes as external cues and sensory attributes convey information as external cues. Furthermore, abstract construal cues, whether internal or external, can dominate concrete cues in shopping (Lamberton and Diehl, 2013).

A label can be expressed as the information attached to a product that can help in establishing a positive attitude. The attitudes and beliefs of a particular product influence the buying intention of that product (Fishbein and Ajzen, 1975). Lancaster (1966) reported that consumers maximise their utility by accumulating bundles of product characteristics. Therefore, like other external and internal attributes, consumers look for process attributes that also work as signals of product quality (Roosen, 2003). However, labelling of product attributes can be costly if expensive tests are necessary to confirm a food's safety characteristics. Responding to these difficulties, firms and regulators have extended their labelling and product differentiation efforts to process attributes (Roosen, 2003). Examples include the labelling of UHT for extended shelf life. This categorisation influences the label's perception and consumers' buying intentions (Jeddi and Zaiem, 2010). Thus, consumers rely heavily on product labels both to distinguish between separate categories of product and to distinguish between products within categories (Hoyer, 1984; Smith and Houston, 1985).

As a fundamental ingredient of dairy products, milk is considered a fundamental food element for all mammals (Kurajdova and Petrovicova, 2015). Milk can be of different types: raw liquid milk (RLM); powdered; condensed; and processed. RLM can be collected and processed using several techniques such as ultra-high temperature treatment (UHT), pasteurisation (conventional), and sterilisation. Although RLM is processed by UHT or pasteurisation to kill bacteria, it is still fresh milk (Lederman, 2004; Charles, 1992) and treated as a product (Nijssen and Van Trijp, 1998). Any dairy product can theoretically be graded and this has traditionally been 
conducted on Cheddar cheese, butter, and skim-milk powder (Yüceer and Drake, 2013). In Cheddar cheese grading, the sensory attribute "mealy" is usually used (Clark et al., 2008) and milk fermented by a probiotic organism has been found to be comparable in sensorial attributes to commercial dairy products (Trivedi et al., 2014). Among the sensory methods, the descriptive sensory analysis has been extensively employed in dairy products' evaluation to identify and measure those attributes that best characterize their sensory properties. For instance, descriptive sensorial analysis has recently been applied to yoghurts (Cliff et al., 2013). Among all the sensory characteristics of milk, flavour is one of the most important attributes for acceptability and preference by consumers (Thomas, 1981; Kim and Morr, 1996) and documented descriptive terms include cooked, brothy, cheesy, tortilla, and malty (Smith et al., 2016).

As brands are not significant in fresh milk, search attributes, rather than experience attributes, are the most important means of evaluation in this situation. Taste and texture are experience attributes, while shape and colour are search attributes. Search attributes are comparatively less brand-sensitive than experience attributes. In addition, brand sensitivity is influenced by the functional characteristics of products. As fresh foods are functional products, a brand will not add much weight or value (Riezebos and Zimmerman, 2005). Therefore, texture is a key quality attribute used in the fresh and processed-food industry to assess product quality and acceptability (Chen and Opara, 2013). In food choices, the taste of the product is crucial (Sijtsema et al., 2012), represented by five basic tastes: sweet; sour; salty; bitter; and umami (a savoury, meaty kind of taste) (Sijtsema et al., 2010). Although fresh milk is the most consumed, marketed and processed dairy food product (FAO, 2013), there is a lack of research on the influence of labels and product cues on consumers' intention to buy.

\section{Hypotheses and conceptual model}

Literature has shown that the product label is valuable to consumers since it increases their level of product involvement, allowing them to distinguish one product from others (Fernandez-Barcala and Gonzalez-Diaz, 2006). Therefore, we propose the following hypothesis:

$H 1_{a}$ : The perception of labels' information of pasteurised fresh milk, e.g. nutritional facts, increases consumers' intention to buy.

$H 1_{b}$ : The perception of labels' information of UHT fresh milk, e.g. nutritional facts, increases consumers' intention to buy.

Texture, appearance, and taste are regarded as the most important attributes in assessing the quality of food products (e.g. Chen and Opara, 2013; Singham et al., 2015). Although there are no specific taste, appearance, or texture components of sampled milk, a mix of sensory attributes, e.g. sweet, sour, salty, umami, heating, frying, odour, and colour, are nevertheless important to assess the quality of milk. Blair (2012) stated that, in the purchase decision, the odour and appearance of food products are two important sensory attributes. This lead us to believe that purchase intention is higher for fresh milk with a higher perception of sensory attributes. Therefore, the second hypothesis of the study is:

$H 2_{a}$ : The perception of sensory attributes of pasteurised fresh milk influences consumers' intention to buy.

$H 2_{b}$ : The perception of sensory attributes of UHT fresh milk influences consumers' intention to buy. 
Literature has also revealed that the product label has impacts on consumers' taste perceptions (Allison and Uhl, 1964; Cavanagh and Forestell, 2013). As intrinsic cue, taste is one of the most important sensory attributes. Thus, the third hypothesis of the study is:

$H 3_{a}$ : The perceived labels' information of pasteurised fresh milk has positive influences on sensory perception.

$H 3_{b}$ : The perceived labels' information of UHT fresh milk has positive influences on sensory perception.

In "causal effect modelling", one should simply discuss the direct, indirect, and total effects among latent variables following the theory or the conceptual model (Schreiber et al., 2006). Hence, an indirect effect implies the effect of an independent variable on a dependent variable through a mediating variable (Baron and Kenny, 1986). In food products, informed liking (consumers' blind liking, evaluation of packaging, brand, product variety, region, etc.) can mediate the relationship between cues and buying intention (Mueller and Szolnoki, 2010). As the sensory attributes are intrinsic cues, the literature leads us to believe that the sensory attributes of fresh milk can mediate the association between the product's labelled information and buying intention. The following hypothesis is proposed:

$H 4_{a}$ : The sensory perceptions of pasteurised fresh milk mediate the relationship between the product labelling and buying intention.

$H 4_{b}$ : The sensory perceptions of UHT fresh milk mediate the relationship between the product labelling and buying intention.

This paper's conceptual model, including these four hypotheses, is presented in Figure 1.

Figure 1. Conceptual model for consumers' buying intention.

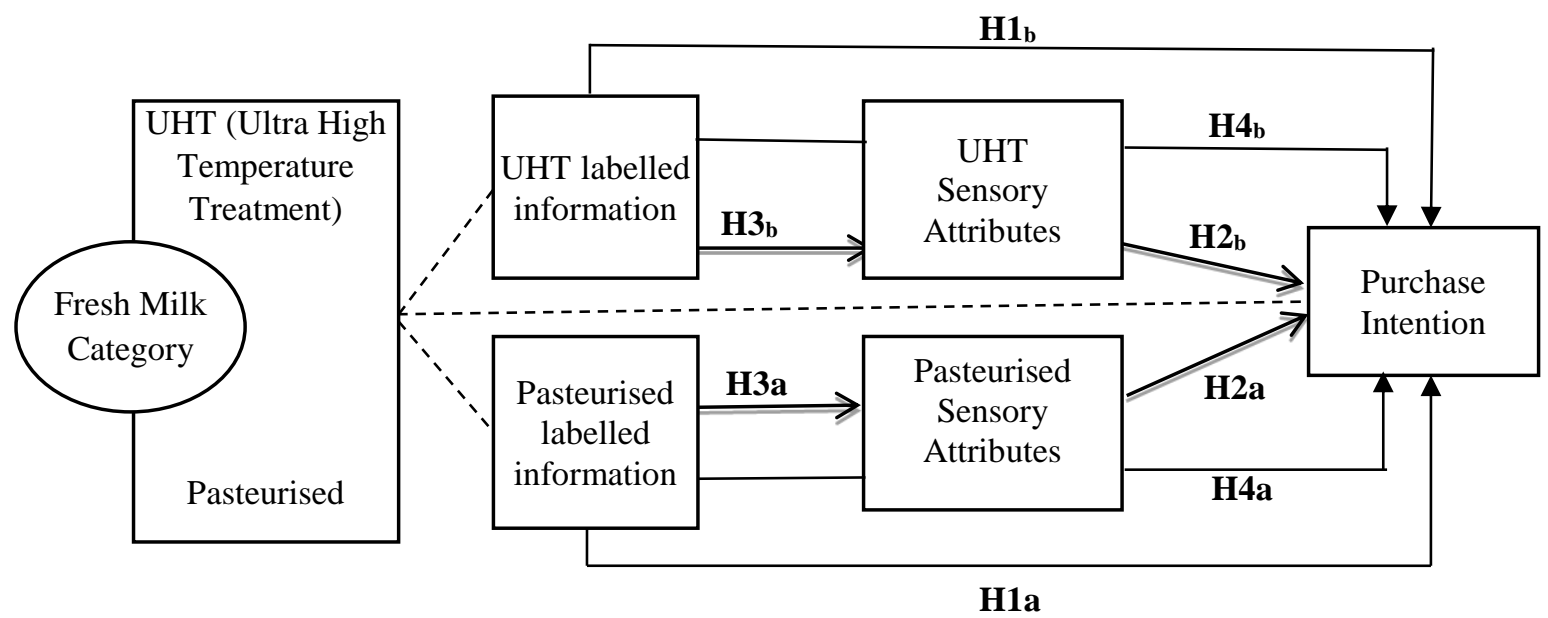




\section{Data and methods}

The study used an experimental design to evaluate the effect of product labels' information and sensory attributes on purchase intentions for two milk categories (UHT and pasteurised). An experimental approach was developed adopting a within-subject design in which each respondent was exposed to two separate treatments: the same subjects were not tested twice using the same type of treatment or test. There was no control or treatment group; participants directly responded with textual information by completing a survey regarding demographic variables and general knowledge about fresh milk. In the second stage, they were offered two types of milk and asked to taste them; they were then asked complete the questionnaire about their taste perceptions. There was no comparison between before and after the experiment; only an evaluation of two fresh milk categories was sought. Thus, the framework of the study is context driven, i.e. fresh milk products (UHT and pasteurized milk). In our study, only UHT and pasteurized milk were selected because they are dominant milk categories in the Bangladeshi milk market. Furthermore, since it was not realistic to include all the UHT and pasteurized milk products in the experiment, we only presented to the participants the most popular product with no label (manipulated) from each category: UHT milk from the PRAN company; and pasteurized milk from the ARONG company.

The experiment was designed and conducted in a lab at the University of Chittagong in Bangladesh. The faculty, staff, and master's students of the university participated in this experiment. Respondents were randomly selected. A pre-test of the experiment with ten participants was performed to improve the questionnaire and experimental design. The ratio of the ten participants was five master's students, three faculty, and two non-academic staff from the Faculty of Business Administration. Based on their responses, we improved the clarity of the questionnaire, the suitability of the participants, the time required. As we did not find any major obstacles, we decided to keep the same settings for the final experiment. A total of 117 individuals participated in the final experiment, which was carried out between 15 September and 10 October 2016. Each session was run with around 10 respondents after the lunch period (between 14.00 hours to 15.00 hours) over 12 days. For strong intercorrelations, a sample size of 150 observations should be sufficient for reliable exploratory factor analysis (EFA) (Guadagnoli and Velicer, 1988). For confirmatory factor analysis (CFA), a minimum sample size of 100 is recommended (Bollen, 1989). Sekaran (2003) considered the appropriate size of a sample to be between 30 and 500. Minimum requirements were, therefore, satisfied in the current study.

During the experiment, the labelled information was written down on a piece of paper and first presented to the respondents (Appendix 1). After closely inspecting the milk labels, participants were asked to fill in the questionnaire using the direct interview method. The order in which labels were presented (PFM vs UFM) was randomised and reflected in the questionnaire. Then a bag was given to each participant containing the two kinds of fresh milk (PFM and UFM), both in $200 \mathrm{ml}$ neutral bottles with only information regarding UHT or pasteurised presented to avoid participants' biased judgement on sensory attributes that might be induced by product labels. During the experiment, the aseptic condition was maintained carefully. Both types of milk were preserved at the same temperature. To control bacteria, personal protective equipment was worn, bottles were checked to be intact, and two candles were lit within $10 \mathrm{~cm}$ while one type of milk was poured from a bottle to a disposable glass for tasting. Water and crackers were provided to neutralize taste and flavour before the other type of milk was tasted. 
Descriptive analysis, EFA, CFA and SEM were used in the study. As EFA helps in summarizing the information received from a dataset, it is extremely useful to conduct EFA (Hair et al., 2009). Here, EFA was used to determine an optimum number of dimensions, their mutual associations based on responses on particular items, and to form a pattern matrix. Based on the pattern matrix of EFA, CFA was used to justify the fitness of our model. SEM was used to measure the cause-and-effect relationship between the factors. For instance, to test $H 1$ and $H 2$, intention to buy was the dependent variable (DV) and the consumer's perception of labelled information and sensory attributes were independent variables (IV). To test $H 3$, the perception of sensory attributes was the DV and perceptions of labelled information were the IV. The normality and multicollinearity of the data was also checked. To address concerns of confounding from the carryover and demand effect of the design, the paired sample correlation and the repeated measures of ANOVA were employed (see Appendices 2, 3 and 4).

\subsection{Measures and questionnaire}

The items for questions included in the questionnaire were developed based on the literature review. The questionnaire had three sections. Section one consisted of consumers' consumption frequency and their attitude towards milk. Section two consisted of perceptions of labelled information, sensory information, and purchase intention, separately. The label information covered nutrition, fat, weight, shelf life, price, safety inspection, instructions, etc., which are typically presented on the product package. For instance, participants were asked to answer to what extent they agreed with a statement like "It displays standardized nutritional facts of milk". The sensory attributes included intrinsic attributes such as tasty, cheesy, colour, textural, flavour, etc. The respondents were asked to answer to what extent they agreed with statements like "It has a good flavour". Purchase intention incorporated consumers' buying information was measured by questions such as: "To what extent are you willing to buy the pasteurised liquid milk at this time?", "To what extent are you willing to buy the UHT liquid milk at this time?" (a five-point Likert scale, from "not at all" (1) to "totally agree" (5) was used); and "What do you think of Pasteurised liquid milk?", "What do you think of UHT liquid milk?" (a five-point Likert scale, from "This milk does not please me totally" (1) to "I really like this milk" (5) was used. Section three covered personal information, including age, income, education, gender, and living status. Eight questions concerning product labels and 13 questions regarding consumers' perceptions of sensory attributes were asked; EFA considered three and six questions for labels and sensory attributes, respectively, explaining $46.62 \%$ of total variance in the UFM model. In the PFM model, EFA considered two questions on labels and three questions on sensory attributes, explaining $57.10 \%$ of total variance.

The Kaiser-Meyer-Olkin (KMO) test and Bartlett's test of sphericity (BTS) were used to verify the factorability of data (Pallant, 2007) and the value of the KMO (in the first test) ranged from 0 to 1 . For an appropriate analysis, the value should be at least 0.60 with a BTS significant at $p<0.05$ ) (Tabachnick et al., 2001). The results of the EFA are shown in Table I.

Table I. Outcome of EFA.

\begin{tabular}{|c|c|c|c|c|}
\hline & \multicolumn{2}{|c|}{ PFM model } & \multicolumn{2}{|c|}{ UFM model } \\
\hline & Laten & variable & Laten & variable \\
\hline Observed variable & Label & Sensory & Label & Sensory \\
\hline Nutritional facts & 0.80 & & 0.70 & \\
\hline Taking responsibility for one's health & 0.61 & & 0.75 & \\
\hline Get answers to questions & & & 0.69 & \\
\hline Dietary information & & & 0.68 & \\
\hline
\end{tabular}




\begin{tabular}{|c|c|c|c|c|}
\hline Fat information & & \\
\hline Health claims & & \multicolumn{3}{|c|}{0.60} \\
\hline Taste & & \multicolumn{3}{|l|}{0.89} \\
\hline Flavour & & \multicolumn{3}{|l|}{0.73} \\
\hline Hedonic & & \multicolumn{3}{|l|}{0.65} \\
\hline Fermented & & & & 0.63 \\
\hline Mealy & & & & 0.68 \\
\hline Umami & & & & 0.60 \\
\hline Cronbach's alpha & 0.67 & 0.80 & 0.84 & 0.68 \\
\hline KMO Score & \multicolumn{2}{|c|}{0.65} & \multicolumn{2}{|c|}{0.82} \\
\hline Bartlett's test of sphericity & \multicolumn{2}{|c|}{$p<0.05$} & \multicolumn{2}{|c|}{$p<0.05$} \\
\hline Total variance explained (\%) & \multicolumn{2}{|c|}{46.62} & \multicolumn{2}{|c|}{57.10} \\
\hline Determinant of correlation matrix & \multicolumn{2}{|c|}{$0.232>0.001$} & \multicolumn{2}{|c|}{$0.056>0.001$} \\
\hline
\end{tabular}

Note: Extraction method: principal axis factoring.

In our data set, the KMO for PFM and UFM were 0.65 and 0.82 , respectively, indicating mediocre suites of data for factor analysis where the minimum required score is 0.60 . The models' BTS of were satisfied, showing sample adequacy. Hair et al. (2009) recommended a score of $>0.50$ for loadings to demonstrate practical significance. From EFA, 14 items were derived with a value $>0.60$, showing the constructs were practically significant (Table I). Reliability was tested using Cronbach's alpha. The cut off rate of Cronbach's alpha was set at 0.60 (Hair et al., 2010). The Cronbach's alpha value for the perceived label's construct for the PFM model was 0.67 and 0.68 for the UFM model. The Cronbach's alpha values for other constructs used in the model were either 0.80 or more (Table I). We established convergent validity by examining the t-tests $(p<0.01)$ for factor loadings, and all were significant (Matthew, 2005). We also established discriminant validity using the confidence interval test $(p<0.05)$ of the mean score of perceived labelled information and sensory attributes (Hatcher, 1994). The average real factor loading score was 0.7. Factor loadings scores higher than 0.6 plus zero cross loading also ensured the convergent and discriminant validity, respectively. Furthermore, the theory also supports the validity of the constructs. Two most popular methods, variance inflation factor (VIF) and tolerance (TOL) have been used to detect the occurrence of multicollinearity problems for explanatory variables (Verbeek, 2008). A general rule of thumb is that a VIF of 10 or greater and a TOL of 0.10 or less may indicate the presence of multicollinearity. Test results suggested no multicollinearity problems in our dataset (Appendix 3). Furthermore, a value higher than 0.001 for the determinant of the correlation matrix of 0.001 in both models was found (PFM, determinant $=0.056$; UFM, determinant $=0.232$ ), also showing no multicollinearity problems (Field, 2000, p. 445).

In a within-subject analysis with a series of questions, order-response correlations analysis can help understand whether questions were answered independently (Charness et al., 2012). As this is the case in our study, we verified the modes of respondents' answers using paired sample correlation and results revealed that, for the PFM model, $\mathrm{r}=0.26(p=0.005)$, and for the UFM model, $\mathrm{r}=0.24$ ( $p=0.009$ ), indicating respondents' independence (no experimenter demand effects) in answering the questions. Smith et al. (1989) applied a similar method and their results yielded a within-confidence accuracy correlation of 0.17 . Additionally, to test if the mean of the two treatments was significantly different from each other, we ran tests of within-subjects contrasts under the repeated measures of ANOVA in SPSS. The results showed that the mean value of two 
treatments were significantly different from each other $(\mathrm{F}=5.611, p=0.019$ for PFM; $\mathrm{F}=24.912$, $p=0.000$ for UFM) showing minimum learning effects.

\section{Results and analysis}

Participants' demographics are presented in Table II. The majority of the respondents were male (72\%), 50\% of the respondents were between 25 and 30 years old, and $51 \%$ of the respondents lived with their parent(s). Only $21 \%$ of respondents lived together with their partner (9\% living with parent(s), partner, and children). The average monthly income of $50 \%$ respondents was equal to or less than BDT 5,000 (c. US\$62).

Table II. Descriptive statistics of demographic variables and general knowledge about fresh milk.

\begin{tabular}{|c|c|c|c|c|c|}
\hline Valid & Missing & Mean & S.D. & Skewness & Kurtosis \\
\hline Drinking frequency daily (times) & $117 \quad 0$ & 0.95 & 0.60 & 0.75 & 2.62 \\
\hline Buying frequency weekly (times) & 117 & 3.81 & 2.29 & 0.32 & 1.27 \\
\hline Know UFM variety ${ }^{\mathrm{a}}$ & 117 & 3.15 & 1.03 & -0.29 & -0.33 \\
\hline Know PFM variety ${ }^{\mathrm{a}}$ & 117 & 3.98 & 1.00 & -0.80 & 0.09 \\
\hline Gender ("M"=1, "F"=2) & 117 & 1.28 & 0.45 & 0.98 & -1.05 \\
\hline Occupation ("S"=1, "P"=2) & 117 & 1.16 & 0.37 & 1.85 & 1.46 \\
\hline Income $^{b}(1=<5 ; 2=5-25 ; 3=>25)$ & 117 & 1.91 & 1.22 & 1.58 & 2.11 \\
\hline Age $(1=20-25 ; 2=25-30 ; 3=>30)$ & 117 & 1.79 & 0.75 & 0.85 & 0.81 \\
\hline Living status ${ }^{\mathrm{c}}$ & 117 & 3.84 & 1.75 & -0.69 & -1.14 \\
\hline
\end{tabular}

Notes: "Very unknown" (1) to "very famous" (5). ${ }^{\text {b }}$ Income in BDT $\times 1,000$.

c 1 =roommate; $2=$ =alone; $3=$ me and my husband/wife; $4=$ me and my husband/wife with children; $5=$ me with parents; $6=$ me, my husband/wife, children and parents. 
On average, the participants drank fresh milk once in a day and bought milk three times per week. The tendency to buy fresh milk was high. The mean of familiarity with UFM was 3.15 and with PFM was 3.98, indicating that PFM was more familiar to customers than UFM.

Table III presents the sources of the variables used in the study for labelled information and shows descriptive statistics for self-reported scores for the eight types of labelled information. The list is topped by information on nutrition and fat information, followed by taking responsibility for one's health, proof of health claims, sales and usage information, and dietary information, based on the combined average of the self-reported scores for both types of fresh milk. Providing information enabling consumers to find answers to all their questions, and the ability to reproduce factsheets, came out last.

Table III. Self-reported perceptions of labelled information.

\begin{tabular}{|c|c|c|c|}
\hline \multirow[b]{2}{*}{$\begin{array}{l}\text { Milk labels' information } \\
\text { and references }\end{array}$} & \multirow[b]{2}{*}{ Descriptors } & \multicolumn{2}{|c|}{$\begin{array}{l}\text { Mean and standard } \\
\text { deviation of score }\end{array}$} \\
\hline & & PFM & UFM \\
\hline $\begin{array}{l}\text { Nutrition (Kurajdova and } \\
\text { Petrovicova, 2015) }\end{array}$ & $\begin{array}{l}\text { It displays standardized } \\
\text { nutritional facts }\end{array}$ & $3.68 \pm 0.77$ & $3.74 \pm 0.814$ \\
\hline $\begin{array}{l}\text { Fat (Kurajdova and } \\
\text { Petrovicova, 2015) }\end{array}$ & $\begin{array}{l}\text { It provides necessary } \\
\text { information about fats }\end{array}$ & $3.51 \pm 0.837$ & $3.77 \pm 0.770$ \\
\hline $\begin{array}{l}\text { Taking responsibility for } \\
\text { one's health (Mannerbro and } \\
\text { Wallin, 2007; Nagyová et al., } \\
\text { 1998) }\end{array}$ & $\begin{array}{l}\text { Its ingredients help me to take } \\
\text { responsibility for my health }\end{array}$ & $3.50 \pm 0.750$ & $3.51 \pm 0.847$ \\
\hline $\begin{array}{l}\text { Health claims (Bonaventure } \\
\text { and Umberger, 2012) }\end{array}$ & $\begin{array}{l}\text { Health claims are defined and } \\
\text { approved }\end{array}$ & $3.54 \pm 0.737$ & $3.36 \pm 0.914$ \\
\hline Usage (Hatirli et al., 2004) & It provides usage information & $3.43 \pm 0.711$ & $3.56 \pm 0.759$ \\
\hline Dietary (Krešić et al., 2010) & It gives a dietary supplement & $3.30 \pm 0.802$ & $3.47 \pm 0.877$ \\
\hline $\begin{array}{l}\text { Questions (Bonaventure and } \\
\text { Umberger, 2012) }\end{array}$ & $\begin{array}{l}\text { I find answers to all questions } \\
\text { on the label }\end{array}$ & $3.21 \pm 0.90$ & $3.39 \pm 0.900$ \\
\hline $\begin{array}{l}\text { Factsheets (Andrews et al., } \\
\text { 2016) }\end{array}$ & $\begin{array}{l}\text { I can reproduce factsheets } \\
\text { and other materials found in } \\
\text { the label }\end{array}$ & $3.21 \pm 0.680$ & $3.38 \pm 0.807$ \\
\hline
\end{tabular}

Notes: $n=117 ; 1=$ "strongly disagree" and 5="strongly agree". 
Table IV provides the sources of variables used in the study for sensory attributes and shows descriptive statistics of self-reported scores for 13 different types of sensory attributes. The list is topped by colour, freshness and flavour, followed by taste, concentration, textural, hedonic, cheesy, dilute, mealy, umami, and fermented. The sensory attribute "malty" came out last by a significant margin. Finally, only two factors, nutritional facts and taking responsibility for one's health, for both milk types were weighted as common factors and, in taste-testing, respondents could not perceive any common sensory attributes of milk indicating their heterogeneous perceptions (see Table I).

Table IV. Self-reported perceptions of sensory attributes.

\begin{tabular}{|c|c|c|c|}
\hline \multirow[b]{2}{*}{ Sensory attributes and references } & \multicolumn{3}{|c|}{$\begin{array}{|ll|}\text { Description } & \begin{array}{l}\text { Mean and Standard Deviation } \\
\text { of score }\end{array} \\
\end{array}$} \\
\hline & This milk & PFM & UFM \\
\hline $\begin{array}{l}\text { Colour (Blair, 2012; Clark et al., 2008; } \\
\text { Croissant et al., 2007) }\end{array}$ & has good colour & $3.73 \pm 0.72$ & $3.68 \pm 0.76$ \\
\hline $\begin{array}{l}\text { Aroma (Chan and Opara, 2013; Kurajdova } \\
\text { and Petrovicova, 2015) }\end{array}$ & has a fresh aroma & $3.70 \pm 0.73$ & $3.64 \pm 0.87$ \\
\hline $\begin{array}{l}\text { Flavour (Cavanagh and Forestell, 2013; } \\
\text { Clark et al., 2008) }\end{array}$ & has good flavour & $3.54 \pm 0.89$ & $3.54 \pm 0.98$ \\
\hline $\begin{array}{l}\text { Tastes (Cavanagh and Forestell, 2009, } \\
\text { 2013; Croissant } \text { et al., 2007) }\end{array}$ & tastes better & $3.41 \pm 0.93$ & $3.57 \pm 0.99$ \\
\hline $\begin{array}{l}\text { Concentration (Yüceer and Drake, 2013; } \\
\text { Al-Kadamany et al., 2003) }\end{array}$ & is concentrated & $3.31 \pm 0.95$ & $3.44 \pm 0.91$ \\
\hline $\begin{array}{l}\text { Textural (Oupadissakoon et al., 2009; } \\
\text { Sijtsema et al., 2012; Blair, 2012) }\end{array}$ & is textural & $3.19 \pm 0.66$ & $3.40 \pm 0.77$ \\
\hline Hedonic (Clark et al., 2008) & is hedonic & $3.25 \pm 0.87$ & $3.29 \pm 0.88$ \\
\hline Cheesy (Yüceer and Drake, 2013) & is cheesy & $3.22 \pm 0.82$ & $3.31 \pm 0.83$ \\
\hline $\begin{array}{l}\text { Dilute (Drake et al., 2003; Smith } \text { et al., } \\
\text { 2016) }\end{array}$ & is diluted & $3.35 \pm 0.81$ & $3.12 \pm 0.92$ \\
\hline Mealy (Clark et al., 2008) & is mealy & $3.26 \pm 0.82$ & $3.21 \pm 0.88$ \\
\hline $\begin{array}{l}\text { Umami (Sijtsema et al., 2012; Yamaguchi } \\
\text { and Ninomiya, 2000) }\end{array}$ & is umami & $3.13 \pm 0.82$ & $3.22 \pm 0.91$ \\
\hline $\begin{array}{l}\text { Fermented (Yüceer and Drake, 2013; } \\
\text { Trivedi et al., 2013) }\end{array}$ & is well fermented & $3.18 \pm 0.81$ & $3.05 \pm 0.83$ \\
\hline $\begin{array}{l}\text { Malty (Smith et al., 2016; Oupadissakoon } \\
\text { et al., 2009) }\end{array}$ & is malty & $2.88 \pm 0.92$ & $2.79 \pm 0.80$ \\
\hline
\end{tabular}

Notes: $n=117 ; 1=$ "strongly disagree" and 5="strongly agree".

To know whether labelled information and sensory attributes are important in consumer decision making, the hypotheses presented in Figure 1 were tested. To test the hypotheses, the study developed two SEMs based on the pattern matrix (Table I), one for UHT milk and the other for pasteurised milk. The model results for UHT milk and pasteurized milk are presented in Figures 2 and 3, respectively. SPSS and AMOS Graphics, 24.00 version, were used for factor analysis and the path model analysis. The indices used to measure the goodness of fit are presented in the topright corner of each figure. The results of all indices for each category (absolute fit measure, incremental fit measure, and parsimonious fit measure) meet the requirements for adequate 
evidence of model fit, indicating construct validity (Haque et al., 2015). The results of the hypotheses for the PFM and UFM models are also presented in Figures 2 and 3, respectively. These figures represent direct and indirect effects of dependent and independent variables. Milk information as labelled facts (Label) has a direct effect on buying intention (Intention), as does the perceptions of sensory attributes (Sensory) and an indirect effect (through estimating the perceptions of sensory attributes) on buying intention. The total effect for milk information as "Label" is the summation of the direct and indirect effect on "Intention".

Figure 2. Tested model of label, sensory attributes, and buying intention for PFM.

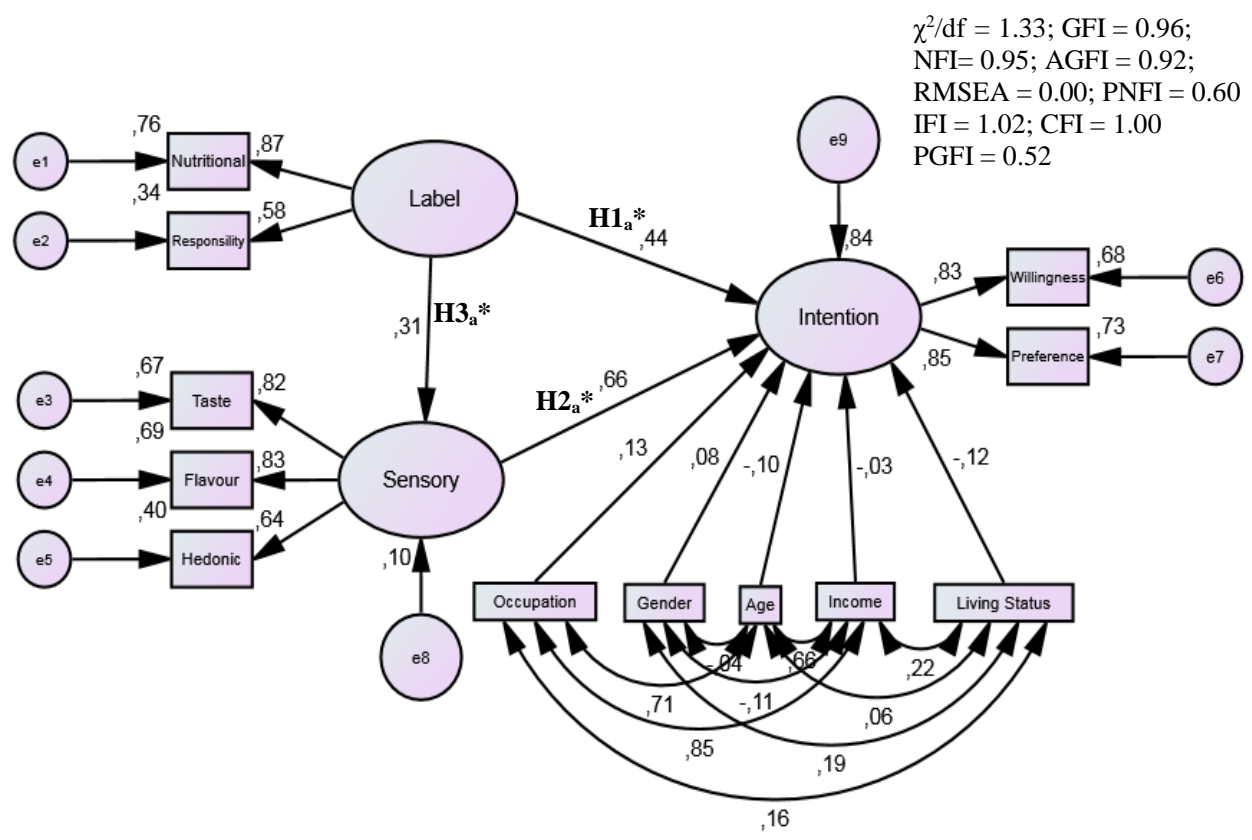

Notes: * Coefficients are significant at a level of 0.01 . GFI=goodness of fit index, AGFI=adjusted goodness of fit index, PGFI=parsimony goodness fit index, $\chi^{2} / \mathrm{df}=$ normed chi-square, $\mathrm{IFI}=$ incremental fit index, $\mathrm{PNFI}=$ parsimony normed fit index, CFI=comparative fit index, RMSEA=root mean square error of approximation. In the model, e1 .. e 7 indicate their adequacy in assessing the related unobserved factors and e 8 and e9 measure residual error or disturbance in the prediction of unobserved factors. The outcome of EFA provides two and three scale items of label and sensory respectively based on the respondents' higher relative weights. 
Figure 3. Tested model of label, sensory attributes, and buying intention for UFM.

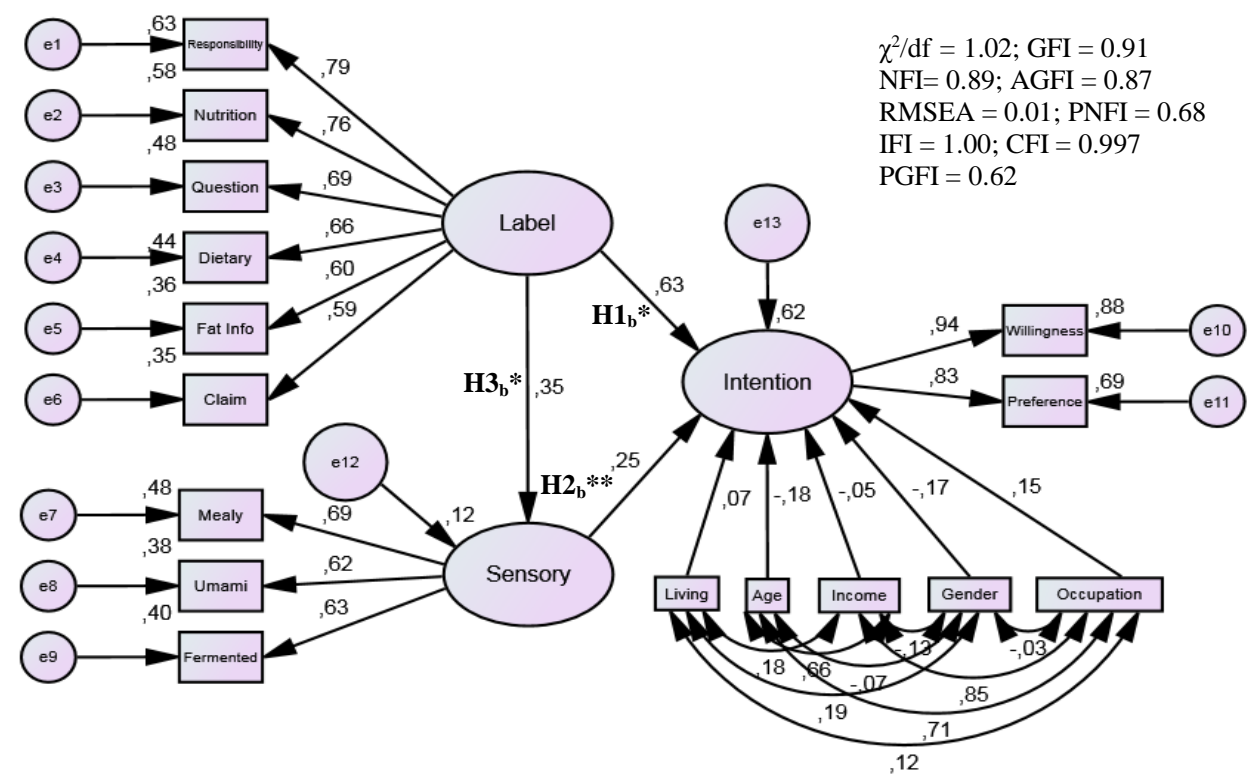

Note: * Coefficients are significant at a level of 0.01 , ** coefficients are significant at a level of 0.05. GFI=goodness of fit index, AGFI=adjusted goodness of fit index, PGFI=parsimony goodness fit index $(\mathrm{PGFI}), \chi^{2} / \mathrm{df}=$ normed chi-square, $\mathrm{IFI}=$ incremental fit index, $\mathrm{PNFI}=$ parsimony normed fit index, $\mathrm{CFI}=$ comparative fit index, RMSEA=root mean square error of approximation. In the model, e1 ... e11 indicate their adequacy in assessing the related unobserved factors and e12 and e13 measure residual error or disturbance in the prediction of unobserved factors. The outcome of EFA provides six and three scale items of label and sensory respectively based on the respondents' higher relative weights.

The results suggest label information has a significant influence on consumers' intention to buy for both PFM and UFM. This supports $H 1_{a}$ and $H 1_{b}$. The model results also show that the label of UFM has a stronger effect (0.63) on buying intention than that of PFM (0.44) and that respondents weighted only two observed variables (nutrition and health responsibility) to the construct "Label" in the PFM model, while there are six in the UFM model. According to our results, nutritional facts and taking responsibility for one's health are the key to fresh milk commercialization in terms of higher relative weights and commonness. For these two common variables, the factor loadings for nutrition were greater in the PFM model than in the UFM model, while the opposite was true for the loadings for taking responsibility for one's health. Besides nutrition and taking responsibility for one's health, there were more information variables in the UFM model, including the getting answers to all question, dietary information, fat information, and health claims (Appendix 1). These results indicate that consumers give different values to the label information presented by the two milk products.

Results suggest that sensory attributes significantly affect consumers' intention to buy both for PFM and UFM, supporting $H 2_{a}$ and $H 2_{b}$. PFM and UFM models both included three sensory attributes variables based on the respondents' higher relative weights. However, we found no common sensory-attribute variables between two models. This indicates consumers' perceeived value of sensory attributes are heterogeneous. In the PFM model, consumers weighted the sensory perceptions taste, flavour, and hedonic feelings. In the UFM model, consumers weighted three 
different attributes (mealy, umami, and fermented), indicating reduced flavour and taste in UHT milk. Results of the perceptions of labelled information suggest labelled information significantly affects consumers' sensory attributes both for PFM and UFM, supporting $H 3_{a}$ and $H 3_{b}$. The effects of labelled information on the sensory attributes both for PFM (0.31) and UFM (0.35) were not large. This indicates consumers' higher perceived values of label information may not lead to higher perceptions to sensory attributes. The results for sensory attributes also suggest that sensory attributes for PFM can mediate the relationship between product labelling and buying intention, indicating an indirect effect of "Label" on "Intention" supporting $\mathrm{H} 4_{\mathrm{a}}$. This mediating effect implies that sensory attributes are able to explain the relationship between labelled information and buying intention. However, this relationship is not true for UFM, therefore, not supporting $H 4_{b}$. In both models, willingness to buy and preference have a much greater importance in explaining the buying intention of milk. This implies that consumer satisfaction and willingness to buy lead to increased consumer buying intentions for both types of fresh milk.

From the results shown in Figure 2, we found evidence to support $H 1_{a}$, indicating that a distinct product label increases the consumers' buying intention for PFM (standardized regression weight=0.44; standard error $(\mathrm{SE})=0.227$; critical ratio $(\mathrm{CR})=4.143$; significant at the 0.000 level). $H 2_{a}$ posited that consumers' sensory perceptions have a significant positive influence on consumer buying intentions for PFM. This hypothesis was supported (standardized regression weight $=0.301$; $\mathrm{SE}=0.158 ; \mathrm{CR}=2.468$; significant at the 0.005 level). The structural-path estimates for $H 3_{a}$ (standardized regression weight $=0.662 ; \mathrm{SE}=0.204 ; \mathrm{CR}=5.430$; significant at the 0.05 level) led to $H 3_{a}$ not being rejected.

To confirm the mediating effect of sensory perceptions, the path coefficients of label perception to sensory perceptions and sensory perceptions should be multiplied by the path coefficient of sensory perceptions to buying intention. At the same time, the multiplied value should be equal or greater than the threshold value (0.08) (Haque et al., 2015) and statistically significant (Rucker et al., 2011). For PFM model, the corresponding multiplied coefficient was $0.20(0.31 \times 0.66=0.2046)$, which is greater than the threshold value $(0.08)$. Sobel's test also showed the $p$-value was 0.024 , suggesting statistical significance at the $5 \%$ critical level. These results provide evidence to support $H 4_{a}$ : sensory perceptions mediate the relationship between labelled information and buying intention in consumers' purchase of PFM. We also found that controlling variables like gender, income, age, occupation, and living status have no significant effect on the buying intention of PFM.

We found evidence from Table 4 and Figure 3 to support the $H 1_{b}$ : a distinct product label increases the consumers' buying intention of UFM (standardised regression weight $=0.631$; $\mathrm{SE}=0.231 ; \mathrm{CR}=5.153 ; p=0.000$ ). $H 2_{b}$ (consumers' sensory perceptions have a significant positive influence on consumer BI of UFM) was also supported (standardized regression weight $=0.252$, $\mathrm{SE}=0.204 ; \mathrm{CR}=2.393 ; p=0.017$ ). Finally, we do not reject the $H 3_{b}$, which posited that consumers' positive perceptions with UFM have a positive and significant effect on the consumer's sensory perceptions (standardized regression weight=0.348; $\mathrm{SE}=0.133 ; \mathrm{CR}=2.546 ; p=0.011$ ).

As in the PFM model, we further tested the mediating effect of sensory attributes in the UFM model. We found the multiple coefficient to be $0.087(0.35 \times 0.25=0.087)$, which is equal to the threshold value (0.08). However, the $p$-value of the multiplied coefficient suggested that it was not statistically significant at any reasonable level. This means sensory perceptions cannot mediate the relationship between labelled information and buying intention of UFM rejecting $H 4_{b}$. Therefore, the mediating effect of sensory perceptions for the two milk categories is inconsistent. 
Similar to results in PFM model, we found variables like gender, income, age, occupation, living status, had no significant effect on the buying intention for UFM.

\section{Discussion and conclusion}

The research has examined the influence of the perceptions of products' labelled information and sensory attributes on consumer's buying intention for fresh milk. To address this research question, four hypotheses were generated and tested. An experimental design was conducted to collect the relevant data. The products' labelled-information scale was formed then regressed with SEM to see if the labelled information increased consumers' buying intention. The results support $H 1$ : products' labelled information increases consumers' buying intention to buy fresh milk (Pasteurised and UHT). Furthermore, consumers' perceived value also indicates that they like to view detailed information about milk on labelling.

$H 2$ posited that the perception of sensory attributes positively influences consumers' intention to buy and was supported both for PFM and UFM, implying that the perception of sensory attributes of fresh milk positively influences consumers' intention to buy. Our findings are similar to those of Espejel et al. (2008) who found that sensory attributes like colour, taste, and smell enhance consumers' perceptions and increase repurchase intention through higher loyalty and a more positive attitude. The present study also found that consumers' perceptions of sensory attributes for PFM and UFM were different in that the perceived value of flavour in UFM was negligible. Steiner (1993) also found that consumers perceive products in highly commoditised product categories as particularly fungible. $H 3$ asserted that perceived product labelled information has a positive influence on sensory perception and was not rejected: labelled information and consumers' sensory perception are positively significantly related. Our finding is consistent with that of Aaron et al. (1994) who found a consistent interactive effect between consumers' sensory perceptions and product labelled information.

$H 4$ posited that sensory perceptions mediate the relationship between the product label and buying intention. The results led to $H 4_{a}$ being accepted for PFM and indicated that the labelled information of PFM has a positive and significant indirect effect on buying intention, but this effect is not true for UFM. Mueller and Szolnoki (2010) found consumers' informed liking mediated the effect of intrinsic and extrinsic cues and the buying intention. In our study, sensory attributes were intrinsic cues and the results demonstrated that level of consumers' informed liking was weaker in UFM than PFM. Furthermore, sensory attributes are more dependent on the individual manufacturing practices and the levels of heat treatment (Oupadissakoon et al., 2009). In the manufacturing process, UFM receives more heat treatment that leads to low-quality flavour, although flavour is considered the key attribute in milk. The findings of the study revealed that the reduced flavour and lower informed liking of UFM are not supportive in mediating the association of labelled information and buying intention and the ultimate result is less acceptability. Other studies have also shown that flavour is a persistent problem for UHT milk in Australia (Melinda and Hilton, 2001) and the UK (Anon, 1994).

Our results indicate that the most important attributes when explaining perceived label information in fresh milk are "standardized nutritional facts" and "information relating to taking responsibility for one's health". With regard to using "usage information" and "ability to reproduce factsheets" as indicators of the perceived label information of milk, both models suggested the elimination of these variables from the model for perceived label information. These findings explain that, as a functional food, consumers are concerned only with the significance fresh milk 
in terms of nutrition and health. They are not interested in excess information, e.g. to reproduce factsheets, that may create a cognitive load. When explaining perceived sensory attributes in fresh milk, the most important attributes are taste, flavour, hedonic, mealy, umami, and fermentation. Regarding the perceived value of PFM, consumers value the sensory attributes of taste and flavour more than other attributes. As they are not fully satisfied with the PFM and they recommend fresh milk for their children (Hatirli et al., 2004), they thus consider the PFM as a hedonic product. Hedonic products are experiential and sensational and people feel more guilt when they contemplate engaging in hedonic consumption than engaging in utilitarian consumption. Additionally, consumers making choices for others are also more likely to choose hedonic over utilitarian options than when deciding for themselves ( $\mathrm{Lu}$ et al., 2016). Regarding the perceived value of UFM, consumers gave more weight to the sensory attributes of umami and fermentation than other attributes. The respondents experienced monotony and were not happy with a taste experienced and they considered UFM as the most mealy product [the texture defects of dairy products or the grainy textures are described by the attribute "mealy" (Chandan, 2016)]. Finally, neither model suggested that the attributes of texture, cheesy, malty, aroma, dilution, or concentration were important in the sensory perception of fresh milk.

\subsection{Managerial implications and further research}

This paper's main theoretical contribution is it the conceptualising and modelling of the factors influencing consumers' purchase intention for fresh milk categories (UHT and pasteurised), based on an experimental design, including perceived product labelled information and sensory attributes. The results of the study demonstrate that useful product label information does have a positive significant effect on purchase intention for fresh milk. Evidence shows that UFM provides more useful information than PFM (Appendix 1) and the ultimate result is that consumers' perceived value for UFM labels is higher than that for PFM labels (Figures 1 and 2). Veale et al. (2006) concluded that marketing practitioners need to understand the respective influence of product category and companies should strive to understand consumers' perceptions of their food products to assure their products' success (see also Varela et al., 2010). The energy content of food products also plays a role in sensory-specific satiety (Sørensen et al., 2003); therefore, it is recommended that marketers should incorporate relevant and useful information regarding energy on milk product labels to increase sensory satiety. Considering the strong influence of a positive perception of the sensory attributes of milk on purchase intention, marketers should focus on strengthening sensory attributes. In doing so, a producer should ensure the quality and safety of milk; consequently, the marketer should engage in communication on their product label to further their recognition. Some actions to be taken could be creating higher levels of sensory perceptions such as: establishing a good savoury taste, e.g. umami; ensuring a pleasant overall flavour, which is determined by the sense of taste, smell, and mouthfeel (Sørensen et al., 2003), and a balanced degradation of protein (caseins) (Smit et al., 2005); ensuring effective fermentation; and making milk non-hedonic and not mealy.

The findings are useful for marketers of fresh food products, especially the sellers of both categories of milk, and the product managers of pasteurised fresh milk. It is surprising that sensory perceptions of UFM cannot mediate the relationship between labelled information and purchase intention. The analysis shows that consumers prefer adequate labelled information of food products and desire a positive sensory perception. Thus, marketers of UFM can try to improve the quality of the flavour, encourage informed likings, and reduce the degree of heating during processing to maintain a good flavour. The benefits of tetra packs and excess heating give UFM 
an extended shelf life (180 days vs 7 for PFM; see Table I) but impair flavour. Smit et al. (2005) found a balanced formation and breakdown of protein (caseins) is important to prevent the accumulation of bitter-tasting peptides, adding that the components of a typical flavour are derived from the activity of amino-acid-converting enzymes. With effective fermentation (e.g. an optimum level of heat) and the presence of adequate levels of amino acids lead to the formation of the key flavour components, which contribute to the sensory perception of dairy products (Smit et al., 2005), the sensory perceptions of milk could mediate the association between product label and buying intention.

The study also helped to fill the gap in the literature regarding how buying intentions' determinants can influence product-development management of fresh milk through its experimental design. Finally, the study has identified that nutritional facts and taking responsibility for one's health are the keys to fresh-milk commercialization. Thus, marketers should provide standardised nutritional facts on product labels and can incorporate information regarding calories, protein, lactose, minerals, sodium, calcium, fat, and shelf life so that consumers understand how a particular milk category is able and ready to meet their needs regarding taking responsibility for one's health. Many existing fresh-food policies, based on direct controls dealing with the nutrition, health benefits and risks, and quality control of the growing, processing, and storing, are not complete because the incorporated controlling techniques have not been thoroughly examined with consumers (Liu et al., 2013). However, in this study, consumer perceptions towards products' labelled information and sensory attributes and the effects of these perceptions on consumers' purchase intentions have been examined by consumers through the experimental design, which can help shape dairy policies and allow marketers to develop more creative solutions.

However, the sample for the study was small. The proposed method of the study would be more effective and would allow the generalization of our findings with a larger strategic sample. Also, the present study collected the data using a within-subject design, which may encourage respondents to be non-independent in questions and tasks (Grice, 1966), and the study may be confounded by range effects (Poulton, 1973). However, the study has employed random assignment of treatments in the design, which is a powerful tool and suggests that it's results are reliable and useable (Charness et al., 2012). Our study was conducted in Chittagong, Bangladesh, and future research should assess other developing economies to verify the validity of the model established in the present study. It would be interesting to verify the model on other functional food product categories, which would also provide external validity. It would be also exciting to test why the perceived value of sensory attributes for UFM was not strong. Finally, we have to note that product labelled information, sensory attributes, and consumers' buying intention may be conditioned by more variables not included in the model, such as perceived health benefits, price, or willingness to pay a premium.

\section{References}

Aaron, J. I., Mela, D. J., and Evans, R. E. (1994). "The influences of attitudes, beliefs and label information on perceptions of reduced-fat spread", Appetite, 22, pp. 25-37.

Alba, J.W. and Hutchinson, J.W. (1987), "Dimensions of Consumer Expertise”, Journal of Consumer Research”, Vol. 13, pp. 411-454.

Al-Kadamany, E., Khattar, M., Haddad, T. and Toufeili, I. (2003), "Estimation of shelf-life of concentrated yogurt by monitoring selected microbiological and physicochemical changes during storage", Leben Wiss Technol., Vol. 36, pp. 407-414. 
Anon. (1994), (as cited in Perkins, M.L. and Deeth, H.C. (2001). "UHT tastes good but fails to win favour". Dairy Ind Int, Vol. 59, pp. 6.

Ares, G., Besio, M., Giménez, A. and Deliza, R. (2010), "Relationship between involvement and functional milk desserts intention to purchase. Influence on attitude towards packaging characteristics", Appetite, Vol. 55 No.2, pp. 298-304.

Asselt, E.D., Capuano, E., Fels-Klerx, and H.J. van der. (2015), "Sustainability of milk production in the Netherlands: A comparison between raw organic, pasteurised organic and conventional milk", International Dairy Journal, Vol. 47, pp.19-26.

Bandara, B.E.S., Silva, D.A.M. and Warunasinghe, W.A.A.I. (2016), "Impact of Food Labeling Information on Consumer Purchasing Decision: With Special Reference to Faculty of Agricultural Sciences", Procedia Food Science, Vol. 6, pp. 309-313.

Banterle, A., Cavaliere, A. and Ricci, E.C. (2012). "Food Labelled Information: An Empirical Analysis of Consumer Preferences”, Int. J. Food System Dynamics, Vol. 3 No. 2, pp. 156-170.

Baron, R. M. and Kenny, D. S. (1986), “The moderator-mediator variable distinction in social psychological research: Conceptual, strategic, and statistical considerations", Journal of Personality and Social Psychology, Vol. 51, pp. 1173-1182.

Bessa, M. E. de., Miriam, P. R. , Marcelo, H. O., Paulo, C. S. , Juliana, M.O., Jucélia, S. B. and Miriam, A. O.P. (2016), "Sensory perception of the fermented goat milk: potential application of the DSC method". Food Sci. Technol, Campinas, Vol. 36 No. (3), pp 406-412.

Bettman, James R., Mary Frances Luce, and John W. Payne. (1998). “Constructive Consumer Choice Processes”, Journal of Consumer Research, 25, Vol. 3, pp. 187-217.

Beverland, M. (2001), "Creating value through brands: the ZESPRI kiwi fruit case", British Food Journal, Vol.103 No. 6, pp. 383-399.

Bhat, Z.F. and Bhat, H. (2011), "Milk and Dairy Products as Functional Foods: A Review", International Journal of Dairy Sciences, Vol. 6 No. 1, pp. 1-12.

Blair, R. (2011), "Is Organic Food more Nutritious and "Tasty"?, in Organic Production and Food Quality: A Down to Earth Analysis, Wiley-Blackwell, Oxford, UK.

Bollen, K. A. (1989). "Structural equations with latent variables". New York: John Wiley \& Sons.

Bonaventure, B. and Umberger, W. (2012), "Factors Influencing Malaysian Consumer's Consumption of Dairy Products", Contributed paper prepared for presentation at the $56^{\text {th }}$ AARES annual conference, Fremantle, Western Australia, February 7-10.

Cavanagh, K. V. and Forestell, C. A. (2013), "The effect of brand names on flavor perception and consumption in restrained and unrestrained eaters", Food Quality and Preference, Vol. 28 No. 2, pp. 505-509.

Charles, P. (1992), "Calcium absorption and calcium bioavailability", Journal of Internal Medicine, Vol. 231, pp.161-168.

Chavas, J. and Klemme, R. (1986), "Aggregate Milk Supply Response and Investment Behavior on U.S. Dairy Farms", American Journal of Agricultural Economics, Vol. 68 No. 1, pp. 55-66.

Chandan, R.C., Arun Kilara, Nagendra P. Shah. (2016). "Dairy Processing and Quality Assurance”, pp.474, Second Edition, John Wiley \& Sons Ltd, Sussex, UK.

Chen, L. and Opara, U. L. (2013), "Texture measurement approaches in fresh and processed foods- A review", Food Research International, Vol. 51, pp. 823-835. 
Cheng, L., Yin, C. and Chien, H. (2014), "Demand for milk quantity and safety in urban China: Evidence from Beijing and Harbin", Australian Journal of Agricultural and Resource Economics, Vol. 59, pp. 275-287.

Clark, S., Costello, M., Drake, M., Bodyfelt, F. (Eds.). (2008), "The Sensory Evaluation of Dairy Products", 2nd ed., Springer Publishing (www.springer.com.)

Croissant A.E., S.P. Washburn, L.L. Dean, and Drake, M.A. (2007), "Chemical properties and consumer perception of fliuid milk from conventional and pasture based production system", J.Dairy Sci. Vol. 90 No. 11, pp. 4942-4953.

Rucker, D. D., Preacher, K. J., Tormala, Z. L., and Petty, R. E. (2011). "Mediation Analysis in Social Psychology: Current Pactices and New Recommendations", Social and Personality Psychology Compass, Vol. 5, No. 6, pp. 359-371.

Drake, M.A. Karagul-Yuceer, Y., Cadwallader, K.R., Civille, G.V., Tong, P.S. (2003). "Determination of the sensory attributes of dried milk powders and dairy ingredients". $J$ Sens Stud, Vol.18, No. 3, pp. 199-216.

Damanpour, F. and Gopalakrishnan, S. (2001). The dynamics of the adoption of product and process innovations in organizations, Journal of Management Studies, Vol. 38, No.1, pp 45-65.

Field, A. (2000). "Discovering Statistics using SPSS for Windows", London - Thousand Oaks - New Delhi: Sage publications.

Foxall, G. R. (2010). "Accounting for consumer choice: Inter-temporal decision making in behavioural perspective", Marketing Theory, Vol 10, Issue 4, pp. 315 - 345.

Gabriel, Yiannis. (2015). "Identity, choice and consumer freedom - the new opiates? A psychoanalytic interrogation", Marketing Theory, Vol 15, Issue 1, pp. 25 - 30.

Grebitus, Carola., Chengyan Yue, Maike Bruhn, and Helen H. Jensen. (2007), "MilkMarketing: Impact of Perceived Quality on Consumption Patterns", Contributed Paper prepared for presentation at the 105th EAAE Seminar 'International Marketing and International Trade of Quality Food Products', Bologna, Italy, March 8-10, 2007.

Guadagnoli, E., and Velicer, W. F. (1988). "Relation of sample size to the stability of component patterns", Psychological Bulletin, 103, 265-275.

Hair, J. F., Black, W. C., Babin, B. J., and Anderson, R. E. (2010). "Multivariate data analysis (7th ed.)", Upper Saddle River, NJ: Pearson Prentice Hall.

Hair, J. F., Bush, R. P., \& Ortinau, D. J. (2009). "Marketing research: In a digital information environment (4th ed.)". New York, NY: McGraw-Hill.

Hatcher, Larry .(1994). "A Step-by-Step Approach to Using the SAS System for Factor Analysis and Structural Equation Modeling". Cary, NC: SAS Institute.

Hatirli, S. Ozkan, B. and Aktas, A. (2004), "Factors Affecting Fluid Milk Purchasing Sources in Turkey", Food Quality and Preferences, Vol.15, pp. 509-515.

Haque, A. Naila, A. Farzana. Y. (2015), "Purchase Intention of Foreign Products: A Study on Bangladeshi Consumer Perspective", SAGE Open. pp. 1-12.

Hussin S. R. Hashim, H., Yusof, R. N. and Alias, N. N. (2013), "Relationship between Product Factors, Advertising, and Purchase Intention of Halal Cosmetic". Pertanika J. Soc. Sci. \& Hum. Vol. 21, pp. 85-100.

Islam, M.A., Subarna Roy, Ashikun Nabi, Sultana Solaiman, Mahdia Rahman, Mohsina Huq, Nurul Amin Siddiquee, Niyaz Ahmed. (2018). "Microbiological quality assessment of " milk at different stages of the dairy value chain in a developing country setting", International Journal of Food Microbiology, Vol. 278, PP. 11-19. 
J Craig Andrews, Chung-Tung JL, Alan SL. (2014). "Consumer Research Needs from the Food and Drug Administration on Front-of-Package Nutritional Labeling", Journal of Public Policy \& Marketing, Vol. 33, No.1, pp.10-16.

Kathuria, L. M. and Gill, P. (2013), "Purchase of branded commodity food products: empirical evidence from India”, British Food Journal, Vol. 115 No. 9, pp.1255-1280.

Kardes, F.R., Kim, J. and Lim, J.S. (2001), "Consumer Expertise and the Perceived Diagnosticity of Inference”, Advances in Consumer Research, Vol.19, pp. 409 - 410.

Khuong, N. M. and Nguyen, D. T. (2015), "The Effects of Television Commercials on Customers Purchase Intention-A Study of Milk Industry in Ho Chi Minh City, Vietnam", Journal of Economics, Business and Management, Vol. 3 No. 9, pp. 851857.

Kim, Y. and Morr, C. (1996), "Dynamic headspace analysis of light activated flavor in milk", International Dairy Journal, Vol. 6, pp. 185-193.

Krešíć, G. Herceg, Z. Lelas, V. and Režek Jambrak, A. (2010), “Consumers’ Behaviour and Motives for Selection of Dairy Beverages in Kvarner Region: a Pilot Study", In Mliekajstvo, Vol. 60 No.1, pp. 50-58.

Kuma, B., Baker, D., Getnet, K. and Kasa. B. (2012), "Factors Affecting Packed and Unpacked Fluid Milk Consumption in Wolaita Zone of SNNP Regional State, Ethiopia”. Ethiopian Journal of Applied Science Technology, Vol. 3 No. 1, pp. 23-11.

Kurajdova, K. and Petrovicova, J. (2015), "Literature review on factors influencing milk purchase behavior", International review of management and marketing, Vol. 5 No. 1, pp. 9-25.

Lancaster, K. (1966), “A New Approach to Consumer Theory”, Journal of Political Economy, Vol.74, 132-57.

Lederman, S.A. (2004), "Influence of Lactation on Body Weight Regulation", Nutrition Reviews, Vol. 62 No. 7, pp. 112-119.

Liu, P.J., Wisdom, J., Roberto, C.A., Liu, L.J. and Ubel, P.A. (2014). "Using Behavioural Economics to Design More Effective Food Policies to Address Obesity". Applied Economic Perspectives and Policy, 36(1), 6-24.

Lu, Jingyi, Zhengyan Liu, Zhe Fang. (2016). "Hedonic products for you, utilitarian products for me", Judgment and Decision Making, Vol. 11, No. 4, pp. 332-341.

Mannerbro, C. and Wallin, G. ( 2007), "Determinants of the Demand for Eco-labelled Milk and Fair Trade Coffee", Stockholm School of Economics, Department of Economics, Master's Thesis in International Economics.

Matthew L. Meuter, Mary Jo Bitner, Amy L. Ostrom, Stephen W. Brown. (2005). "Choosing Among Alternative Service Delivery Modes: An Investigation of Customer Trial of Self-Service Technologies" Journal of Marketing, Vol. 69, No. 2, pp. 61-83.

Miller, L.M.S. and Cassady, D.L. (2015), "The effects of nutrition knowledge on food label use. A review of the literature", Appetite, Vol. 92, pp. 207-216.

Morris, Julian. (1997), "Green goods? Consumers, product labels and the environment", The environment unit the institute of economic affairs, 2 lord north street, Westminster, London sw1p $31 b$.

Mueller, S. and Szolnoki, G. (2010), "The relative influence of packaging, labelling, branding and sensory attributes on liking and purchase intent: Consumers differ in their responsiveness", Food Quality and Preference, Vol. 21 No., pp. 774-783.

Nagyová, L. Stehlíková, B. and Kretter, A. (1998) "Faktory ovplyvňujúce rozhodovanie 
zákazníka pri kúpe mlieka a mliečnych výrobkov", Retrieved from http://www.agris.cz/clanek/105187

Nijssen, E. J. and Van Trijp, H. C. (1998), "Branding fresh food products: exploratory empirical evidence from the Netherlands, European Review of Agricultural Economics, Vol. 25 No. 2, pp. 228-242.

Orquin, J. L. and Scholderer, J. (2011), “Attention to health cues on product packages", $J$. Eyetracking Vis. Cogn. Emot. Vol.1 No. 1, pp. 59-63.

Oupadissakoon, G., D.H. Chambers. and E. Chambers. (2009), "Comparison of the Sensory Properties of Ultra-High-Temperature (UHT) Milk from Different Countries", Journal of Sensories Studies. Vol. 24, pp. 427-440.

Pallant, J. (2007). SPSS survival manual: A step by step guide to data analysis using SPSS (3rd ed.). Berkshire, UK: Open University Press.

Perkins, M.L. and Deeth, H.C. (2001). "A survey of Australian consumers' attitudes towards UHT Milk", Australian Journal of Dairy Technology, Vol. 56 No. (1), pp. 28-34.

Popescu, A. (2015), "The trends in milk production and consumption in Romania", Scientific Papers Series Management, Economic Engineering in Agriculture and Rural Development, Vol. 15 No. 1, pp. 387-592.

Point of Purchase Advertising International. (2014). "Mass Merchant Shopper Engagement Study". Retrieved from http://memberconnect.shopassociation.org

Raghunathan, R. and Irwin, J. (2001), "Walking the Hedonic Product Treadmill: Default Contrast and Mood Based Assimilation in Judgments of Predicted Happiness with a Target Product", Journal of Consumer Research, Vol. 28, pp. 355-368.

Roosen, Jutta. (2003), "Marketing of Safe Food Through Labeling”, Journal of Food Distribution Research, Vol. 34 No. 3, pp. 77-82.

Schreiber, J.B., Amaury Nora, Frances K. Stage, Elizabeth A. Barlow, and Jamie King. (2006), "Reporting Structural Equation Modeling and Confirmatory Factor Analysis Results: A Review", The Journal of Educational Research, Vol. 99 No. 6, pp. 323-338. Sekaran, U. (2003). "Research Methods for Business: A Skill Building Approach (4th ed.)", New York: John Wiley \& Sons.

Sijtsema, S. J., Reinders, M. J., Hiller, S. R., and Guàrdia, M. D. (2012), "Fruit and snack consumption related to sweet, sour and salty taste preferences", British Food Journal, Vol. 114 No. 7, pp.1032-1046.

Smith, R.A. and M.J. Houston. (1983), “A psychometric assessment of measures of scripts in consumer memory", Journal of consumer research, Vol.12, pp. 214-224.

Smith, V., Kassin, S., Ellsworth, P. (1989). "Eyewitness accuracy and confidence: withinversus between-subjects correlations", Journal of Applied Psychology, 74, pp. 356-359.

Smith, T.J., Campbell, R.E., Jo, Y. and Drake, M.A. (2016), "Flavor and stability of milk proteins", Journal of Dairy Science, Vol. 99 No. 6, pp. 4325-46.

Sørensen, L.B., P Møller, A. Flint, M. Martens, and A. Raben. (2003), "Effect of Sensory Perception of Foods on Appetite and Food Intake: a Review of Studies on Humans", International Journal of Obesity, Vol. 27, pp. 1152-1166.

Steiner, Robert L. (1993), "The Inverse Association Between the Margins of Manufacturers and Retailers," Review of Industrial Organization, 8 (6), pp. 717-40.

Tabachnick, B. G., Fidell, L. S., \& Osterlind, S. J. (2001). "Using multivariate statistics (4th ed.)", Needham Heights, MA: Allyn \& Bacon.

Thaler, Richard H., and Cass R. Sunstein. (2008). "Nudge: Improving Decisions about 
Health, Wealth and Happiness", New York: Penguin.

Thomas, E. (1981), "Trends in milk flavours". Journal of Dairy Science, Vol. 64, pp.10231027.

Trijp, Van , H. C., and Meulenberg, M. T. (1996), "Marketing and consumer behaviour with respect to foods Food choice, acceptance and consumption” pp. 264-292, Springer.

Trivedi, Jigarkumar, B., Prajapati, Jashbhai, B., Nair, Baboo, M., Oste, R. and Aparnathi,

K.D. (2014), "Fermentation kinetics and sensory attributes of milk fermented by probiotic bacteria", International Journal of Fermented Foods, Vol. 3 No. 1, pp. 75-84.

Troye, S. V. and Supphellen, M. (2012). "Consumer Participation in Coproduction: "I Made It Myself" Effects on Consumers' Sensory Perceptions and Evaluations of Outcome and Input Product", Journal of Marketing, Vol. 76, No. 2, pp. 33-46.

Van Dam, Y., and Van Trijp, H. (2007), "Branding and labelling of food products". Understanding consumers of food products. CRC Press, Cambridge, pp.153-180.

Varela, P., Ares, G., Gimenez, A. and Gambaro, A. (2010), "Influence of brand information on consumers' expectations and liking of powdered drinks in central location tests", Food Quality and Preference, Vol. 21, pp. 873-880.

Veale, R. Pascale, Q. and Amal, K. (2006), "The role of intrinsic (sensory) cues and the extrinsic cues of country of origin and price on food product evaluation. 3rd International Wine Business \& Marketing Research Conference, Montpellier, 6-7-8 July 2006, Refereed paper.

Verbeek, M. (2008), “A guide to modern econometrics". Wiley.

Wendy Attaya Boland, Merrie Brucks, Jesper H. Nielsen. (2012). "The Attribute Carryover Effect: What the "Runner-Up" Option Tells Us about Consumer Choice

Processes", Journal of Consumer Research, Volume 38, Issue 5, pp. 872-885.

Yamaguchi, S. and Ninomiya, K. (2000), "Umami and food palatability", The Journal of Nutrition, Vol.130 No. 4, pp. 921-6.

Yüceer and Drake. (2013), "Manufacturing Yogurt and Fermented Milks", Second Edition. Edited by Ramesh C. Chandan and Arun Kilara. John Wiley \& Sons, Inc.

\section{Appendix 1: Product Labelled Information (PLI) in a piece of paper}

Full Cream Liquid Milk

\begin{tabular}{|c|c|c|}
\hline Information & $\begin{array}{c}\text { Pasteurized Fresh } \\
\text { Milk (PFM) }\end{array}$ & $\begin{array}{c}\text { UHT Fresh Milk } \\
\text { (UFM) }\end{array}$ \\
\hline Fat & $3.50 \%($ min.) & $3.50 \%(\mathrm{~min})$. \\
\hline Solids No Fat & $8.00 \%($ min.) & $8.00 \%(\mathrm{~min})$. \\
\hline Protein & $3.30 \%($ min.) & $3.2 \mathrm{~g}$ \\
\hline Lactose & $4.40 \%$ (min.) & \\
\hline Minerals & $0.70 \%($ min.) & $3.5 \mathrm{~g}$ \\
\hline Total Fat & & $1.2 \mathrm{~g}$ \\
\hline Saturated Fat & & $4.7 \mathrm{~g}$ \\
\hline Carbohydrate & & $41 \mathrm{mg}$ \\
\hline Sodium & & $122 \mathrm{mg}$ \\
\hline Calcium & & Less than $3 \mathrm{mg}$ \\
\hline Cholesterol & & $63.1 \mathrm{kcl}$ \\
\hline Energy & & \\
\hline
\end{tabular}




\begin{tabular}{|c|c|c|}
\hline Other Information & & \\
\hline Batch Number & XXXX & XXXX \\
\hline Mfg. Date & XXXX & XXXX \\
\hline Exp. Date & 7 days & 180 days \\
\hline MRP & Tk. 62/Litre & Tk. 80/Litre \\
\hline Processed by & XXXX Inc & XXXX Inc \\
\hline Barcode & Yes & Yes \\
\hline BSTI Logo & Yes & \\
\hline ISO Certified & Yes & 1 Liter \\
\hline Weight & 1 Liter & Tetra \\
\hline Type of Pack & Poly & Yes \\
\hline Needs no boiling before use & & Yes \\
\hline Needs no refrigeration till opened & & Yes \\
\hline No preservative added & & \\
\hline Instructions: & & Yes \\
\hline Keep Refrigerated below $4^{0} \mathrm{C}$ & Yes & Yes \\
\hline Keep refrigerated after opening & & Yes \\
\hline Keep in cool \& dry place & & Yes \\
\hline Don't buy Puffed or Leaky Packs & & Yes \\
\hline Cut here to pour & & rXXXX' \\
\hline Keep your country clean & & \\
\hline
\end{tabular}

The word 'yes' indicates that this information is exist on the product label and the symbol 'XXXX' indicates original figure has deleted to keep the respondents neutrals. The empty space indicates, no information in the original label.

\section{Appendix 2: Normality Test}
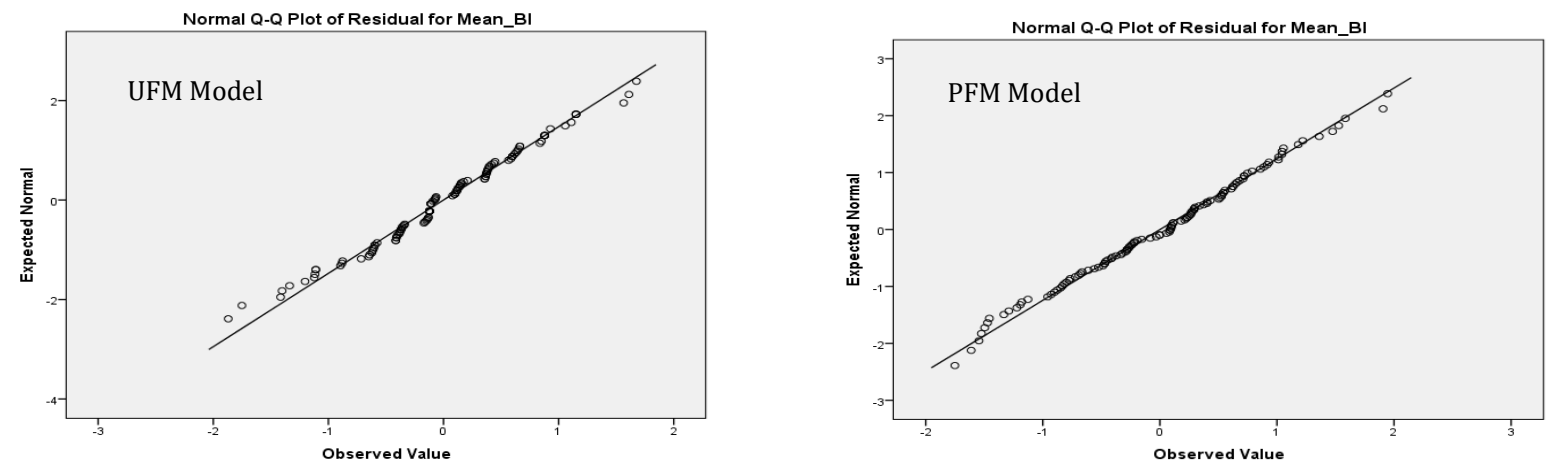

Tests of Normality
\begin{tabular}{|l|r|r|r|r|r|r|}
\hline & \multicolumn{3}{|c|}{ Kolmogorov-Smirnova } & \multicolumn{3}{c|}{ Shapiro-Wilk } \\
\cline { 2 - 7 } & Statistic & \multicolumn{1}{c|}{ df } & \multicolumn{1}{c|}{ Sig. } & \multicolumn{1}{c|}{ Statistic } & \multicolumn{1}{c|}{ df } & \multicolumn{1}{c|}{ Sig. } \\
\hline Residual for Mean_BI & .085 & 117 & .038 & .987 & 117 & .305 \\
\hline
\end{tabular}

a. Lilliefors Significance Correction 
Normality test for UFM

Tests of Normality

\begin{tabular}{|l|r|r|r|r|r|r|}
\hline & \multicolumn{3}{|c|}{ Kolmogorov-Smirnov } & \multicolumn{3}{c|}{ Shapiro-Wilk } \\
\cline { 2 - 7 } & Statistic & \multicolumn{1}{c|}{ df } & \multicolumn{1}{c|}{ Sig. } & Statistic & \multicolumn{1}{c|}{ df } & \multicolumn{1}{c|}{ Sig. } \\
\hline Residual for Mean_BI & .061 & 117 & $.200^{*}$ & .991 & 117 & .610 \\
\hline
\end{tabular}

*. This is a lower bound of the true significance.

a. Lilliefors Significance Correction

\section{Appendix 3: Test of treatment of the experimental design}

2(a): PFM

Tests of Within-Subjects Contrasts

Measure: MEASURE_1

\begin{tabular}{|c|c|c|c|c|c|c|c|}
\hline Source & treatment & $\begin{array}{l}\text { pe III Sum of } \\
\text { Squares }\end{array}$ & df & Mean Square & $\mathrm{F}$ & Sig. & $\begin{array}{c}\text { Partial Eta } \\
\text { Squared }\end{array}$ \\
\hline treatment & Linear & 2,132 & 1 & 2,132 & 5,611 & ,019 & ,046 \\
\hline Error(treatment) & Linear & 44,063 & 116 &, 380 & & & \\
\hline
\end{tabular}

\section{Paired Samples Correlations}

\begin{tabular}{llr|r|r} 
& & N & Correlation & \multicolumn{1}{c}{ Sig. } \\
\hline Pair 1 & MLabel_PFM \& & 117 &, 258 &, 005 \\
& MSensory_PFM & & & \\
\hline
\end{tabular}

2(b): UFM

\section{Tests of Within-Subjects Contrasts}

Measure: MEASURE_1

\begin{tabular}{|c|c|c|c|c|c|c|c|}
\hline Source & treatment & $\begin{array}{l}\text { Se III Sum of } \\
\text { Squares }\end{array}$ & df & Mean Square & $\mathrm{F}$ & Sig. & $\begin{array}{c}\text { Partial Eta } \\
\text { Squared } \\
\end{array}$ \\
\hline treatment & Linear & 8,336 & 1 & 8,336 & 24,912 &, 000 & , 177 \\
\hline Error(treatment) & Linear & 38,816 & 116 & ,335 & & & \\
\hline
\end{tabular}

\section{Paired Samples Correlations}

\begin{tabular}{rlr|r|r} 
& $\mathrm{N}$ & Correlation & \multicolumn{1}{c}{ Sig. } \\
\hline Pair 1 & MLabel_UFM \& & 117 &, 240 &, 009 \\
& MSensory_UFM & & & \\
\hline
\end{tabular}




\section{Appendix 4: Multicolliniarity Analysis}

\section{UFM}

\begin{tabular}{|c|c|c|c|}
\hline \multicolumn{4}{|c|}{ Coefficients $^{a}$} \\
\hline \multirow{2}{*}{\multicolumn{2}{|c|}{ Model }} & \multicolumn{2}{|c|}{ Collinearity Statistics } \\
\hline & & Tolerance & VIF \\
\hline \multirow{9}{*}{1} & Nutrition & .512 & 1.955 \\
\hline & Question & .525 & 1.905 \\
\hline & Claim & .660 & 1.516 \\
\hline & Responsibility & .481 & 2.080 \\
\hline & Fat Info & .607 & 1.649 \\
\hline & Dietary & .592 & 1.688 \\
\hline & Mealy & .665 & 1.503 \\
\hline & Umami & .737 & 1.357 \\
\hline & Fermented & .700 & 1.429 \\
\hline
\end{tabular}

a. Dependent Variable: Mean_BI

PFM

\begin{tabular}{|c|c|c|c|}
\hline \multicolumn{4}{|c|}{ Coefficients $^{a}$} \\
\hline \multirow{2}{*}{\multicolumn{2}{|c|}{ Model }} & \multicolumn{2}{|c|}{ Collinearity Statistics } \\
\hline & & Tolerance & VIF \\
\hline \multirow{5}{*}{1} & Nutritional & .706 & 1.416 \\
\hline & Responsibility & .708 & 1.413 \\
\hline & Taste & .449 & 2.226 \\
\hline & Flavour & .502 & 1.993 \\
\hline & Hedonic & .648 & 1.543 \\
\hline
\end{tabular}

a. Dependent Variable: Mean_BI 